\title{
Butterflies and Moths in the Amazon: Developing Mathematical Thinking through the Rainforest
}

Les papillons en Amazonie: le développement de la pensée mathématique au travers de la forêt pluviale

Brian Hudson

\section{OpenEdition}

\section{Journals}

Electronic version

URL: https://journals.openedition.org/educationdidactique/2322

DOI: 10.4000/educationdidactique.2322

ISSN: $2111-4838$

\section{Publisher}

Presses universitaires de Rennes

\section{Printed version}

Date of publication: 30 September 2015

Number of pages: 119-133

ISBN: 978-2-7535-4284-6

ISSN: 1956-3485

\section{Electronic reference}

Brian Hudson, "Butterflies and Moths in the Amazon: Developing Mathematical Thinking through the Rainforest", Éducation et didactique [Online], 9-2 | 2015, Online since 30 September 2017, connection on 16 August 2022. URL: http://journals.openedition.org/educationdidactique/2322 ; DOI: https://doi.org/ 10.4000/educationdidactique.2322 


\title{
BUTTERFLIES AND MOTHS IN THE AMAZON : DEVELOPING MATHEMATICAL THINKING THROUGH THE RAINFOREST
}

\author{
Brian Hudson \\ University of Sussex, UK
}

This paper reports on a research study conducted with a group of practising primary school teachers $(\mathrm{n}=24)$ in North East Scotland during 2011-12. The teachers were all participants in a newly developed Masters course that had been designed within a didactical design research framework with the aim of promoting the development of mathematical thinking in the primary classroom as part of project supported by the Scottish Government. The paper presents the background for this initiative within the context of the Scottish Curriculum for Excellence reform. It reports on the research design, research questions and methods of data collection of the research study related to the project as a whole. Further it explores the impact on pupil learning arising from the teachers' experiences of this course and, in particular, from the process of classroom inquiry through their action research projects. The analysis of classroom interaction utilises a theoretical framework based on the concept of joint action in didactics. This framework is applied to the analysis of data from one teacher-researcher's action research project based on the development of a topic-based approach to teaching and learning mathematics on the theme of "The Rainforest". The findings from this study highlight the ways in which the children actively engaged in the 'milieu', the ways in which the teacher developed the 'didactic game' by extending the 'epistemic games' through the use of the openended topic-based approach combined with effective teacher questioning. They also highlight the ways in which the discursive elements of 'learning games' as part of these lessons proved to be very effective means through which to support the children to engage in the milieu and to develop mathematical thinking. It was evident in this study that children had very differing prior knowledge and experiences to bring to the problem solving elements of the tasks and that, due to their ability to visualise the problems, the mathematics became more accessible leading to an evolution in mathematical thinking for all.

Keywords: mathematical thinking, primary mathematics, joint action in didactics, comparative didactics, topicbased approaches to teaching mathematics.

Les Papillons en Amazonie : le développement de la pensée mathématique au travers de la forêt pluviale

Cet article présente les résultats d'un projet de recherche mené auprès d'un groupe d'enseignants du primaire $(n=24)$ dans le nord-est de l'Écosse en 2011-2012. Tous les enseignants participaient à un master nouvellement développé qui avait été conçu dans le cadre d'une recherche de conception didactique ayant pour but la promotion du développement de la pensée mathématique dans les classes primaires dans un projet appuyé par le gouvernement écossais. Cet article présente le contexte de cette initiative dans le cadre de la réforme éducative écossaise "le Curriculum pour l'Excellence ". Il décrit le modèle de recherche, les questions de recherche et les méthodes de collecte de données pour le projet dans son ensemble. En outre, il explore l'impact sur le savoir des élèves résultant de l'expérience du master des enseignants et, en particulier, du processus d'enquête en classe à travers leurs projets de recherche-action. L'analyse de l'interaction en classe utilise un cadre théorique basé sur le concept de l'action commune en didactique. Ce cadre a été utilisé pour l'analyse des données provenant du projet de recherche-action d'un des enseignants-chercheurs, qui était basé sur le développement d'une approche thématique à l'étude des mathématiques sur le thème de la "forêt pluviale ». Les résultats de cette étude 
mettent en évidence la manière dont les enfants s'engageaient activement dans le "milieu ", et la manière dont l'enseignant développait le "jeu didactique " en étendant les " jeux épistémiques " grâce à l'utilisation d’une approche thématique ouverte, combinée avec une interrogation efficace de la part de l'enseignant. Les résultats soulignent la façon dont les éléments discursifs de "l'étude ludique " dans ces leçons s'avéraient très efficaces pour soutenir les élèves à s'engager dans le milieu et à développer la pensée mathématique. Il était évident dans cette étude que les enfants apportaient à la résolution de problèmes des connaissances et expériences très différentes, et que, en raison de leur capacité à visualiser les problèmes, les mathématiques devenaient plus accessibles, ce qui entrainait une évolution de la pensée mathématique pour tous.

Mots-clés :pensée mathématique, mathématiques au primaire, action commune en didactique, didactique comparative, approche thématique de l'enseignement des mathématiques.

\section{Acknowledgements}

I wish to acknowledge and to thank the Scottish Government for its support in enabling the project from which this study arose to be carried out. Also I wish to thank Anna who as a teacher-researcher conducted a most interesting and illuminative action research project. Finally I would like to thank Brigitte Gruson especially for her insightful and constructive comments on an early draft of this paper. 


\section{INTRODUCTION}

The background context for this study is the project (DMTPC, 2012) 'Developing Mathematical Thinking in the Primary Classroom' (2010-12) funded by the Scottish Government. The project involved teachers and education support staff from neighbouring local authorities collaborating to develop a Master's level course on this theme involving a technology enhanced blended learning approach. This development took place within the context of 'Curriculum for Excellence', a national curriculum reform in Scotland that was informed by an OECD review of national policy for education in Scotland (OECD, 2007) as part of a wider review of national policies at an international level (Scottish Executive Education Department, 2007). A projectand work-based approach to learning underpinned the course of study that was designed to support a process of classroom-based action research. The course was first piloted during 2011-12 with a group of 24 practising primary teachers.

The project was set against a background in which, despite past initiatives to improve the teaching and learning of mathematics, most mathematics lessons in Scotland still tend to feature some form of teacher-led demonstration followed by children practising skills and procedures from a commercially produced scheme (Scottish Executive Education Department, 2005). These findings were confirmed by TIMSS (IEA, 2008) which found that $72 \%$ of both P5 and S2 pupils were taught using a textbook as the primary resource compared to the international average of $65 \%$ and $60 \%$, respectively. The Scottish Survey of Achievement (Scottish Government,
2009) also reported that pupils using textbooks and working quietly on their own was the most common form of activity in mathematics classes in Scotland. This background context points to the importance of sound subject knowledge and of teacher confidence that is associated with this, raises questions about the nature of mathematics and highlights the considerable role of both teachers' beliefs and the affective dimension in student learning as discussed in Hudson, Henderson and Hudson (2014).

\section{Curriculum DeVelopment Project}

The overall aim of the curriculum development project was to develop and implement a Postgraduate course of Continuing Professional Learning on the theme of "Developing Mathematical Thinking in the Primary Classroom" (DMTPC). The course was designed in the first year of the project (2010-11) to form the first stage in a Masters level programme in Mathematics Education for Primary Specialists in Mathematics and to be accredited as a freestanding module worth 30 credits leading towards a Postgraduate Certificate in Developing Mathematical Thinking. The Curriculum Development Partnership Group that planned the course included one teacher with one from each of the Local Education Authorities (LEA) and two Local Education Authority staff members with one from Fife and the other from Angus. The course design was based on a blended learning model with an online learning environment established in the University Virtual Learning Environment.

Figure 1. Welcome page for the online learning environment

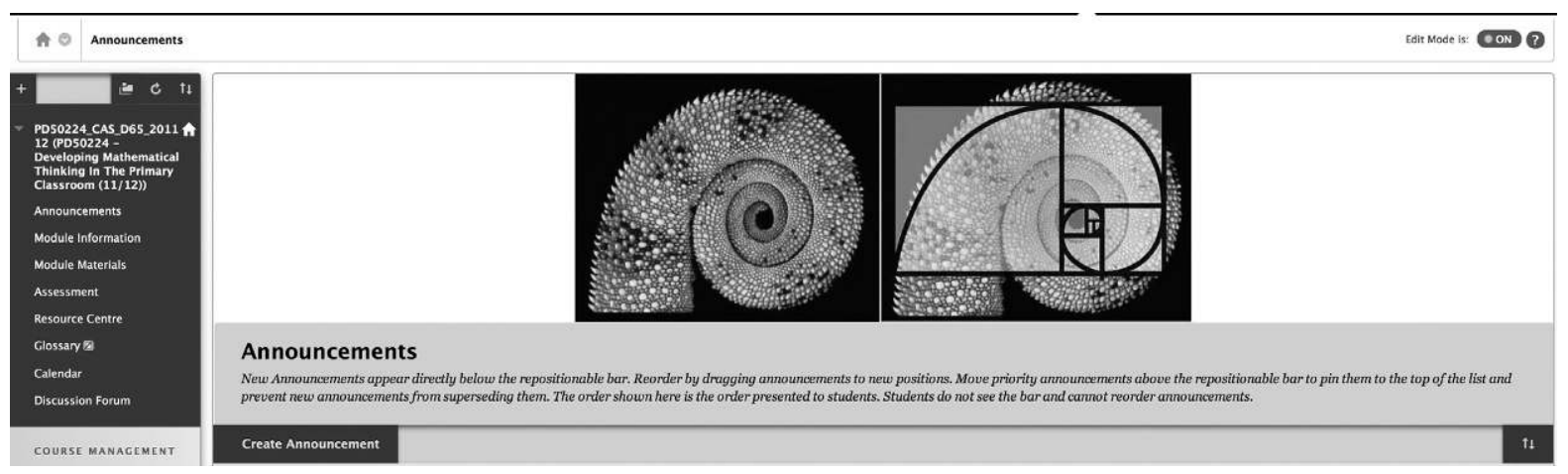


The module was opened in the online environment in September 2011 and was followed closely by the first day workshop. There were two twilight sessions as part of the course that took place in October and December and a final day workshop, which took place in February 2012. For those completing the associated assignment, the submission date was set for April 2012, which marked the end date of the course of study. The group was made up of 23 females and one male, with an age range from 21 to 55 .

The course of study was structured around three key questions, two core texts and an action research project. The key questions were :

1.What is mathematics?

2.What is mathematical thinking ?

3.What is good mathematics teaching?

The core texts were those by Boaler (2009) and Mason et al. (2010) and course assignment was the action research project report. The latter was submitted for the award of 30 Masters level credits in the form of a report of 5000 words. Participants were required to design a project that would consider the implications of current literature on the development of mathematical thinking; identify strategies, skills and attitudes to be developed; identify methods of data collection and analysis that provide evidence of impact; be feasible and realistic in terms of the resources available in school; give consideration to progression and assessment and identify the issues which emerged from the study.

With regard to the action research project, all participants took part in the first planning stage of this process through undertaking an audit of their practice, supported by input from the LEA support staff. This was then used as the basis of the development of an action research plan for a small-scale project designed to develop mathematical thinking in their classrooms. Accordingly formative tutor feedback was given on action plans, which were submitted via the online learning environment. The second stage involved undertaking the project and completing the writing up of the Action Research Project report. In their reports, participants were required to reflect upon the role of the teacher in developing mathematical thinking and promoting good mathematics teaching; indicate how the study had impacted on classroom practice and children's learning with reference to the supportive evidence and to conclude with an evaluative summary of the their own learning from the study and how this might be developed further in the future.

All participants put their ideas into action by carrying out a classroom-based inquiry of which ten submitted Action Research Project reports for formal assessment. Members of the tutor team assessed the reports in May 2012, and all were passed successfully subject only to the need for some minor technical corrections. The projects addressed a diverse and highly relevant range of topics and questions as outlined below :

1. Meeting the challenges of mixed ability mathematics in a multi composite class;

2. An inquiry into the use of non-commercial resources to develop children's mathematical thinking ;

3. Open-ended activities and encouraging collaborative talk with 7-8 year olds.

4. Using real life mathematics in the everyday teaching of the subject to engage and develop mathematical thinking ;

5. An examination of the effects of pupils carrying out open-ended investigations in mathematics and using a variety of media to communicate their mathematical solutions and ideas ;

6. Using questioning to extend the mathematical thinking of infants and to increase the children's ability to decompose and recompose numbers ;

7. To what extent does topic-based mathematics allow children to demonstrate their mathematical thinking ?;

8. How does investigating proofs with Primary 2 develop mathematical thinking ?

9. A collaborative investigation into developing mathematical thinking - making connections

10. How do the teacher's questioning skills have an impact on mathematical thinking ?

The report of the study on topic-based mathematics (7) was judged to be an outstanding achievement and is the main focus of study in this paper. This was identified to be an exemplar of the role of the teacher as researcher at its best, involving innovative and creative planning, spontaneous and responsive classroom action, finely grained classroom observation and insightful evaluation. 


\section{RESEARCH DESIGN}

The project as a whole was set up within a didactical design research framework as described in Hudson (2011) which aims to address the ways in which we might systematically create, test, evaluate and disseminate teaching and learning interventions that will have a maximum impact on practice and contribute significantly to the development of theory about teaching and learning. This approach aims to integrate processes of evaluation and dissemination and to address questions of research, including action research by the course participants, and curriculum development in parallel as captured in Figure 2.

\section{Research questions}

The key research questions addressed in the main study were related to the teachers' perceptions concerning their levels of confidence, competence attitudes and beliefs in relation to teaching mathematics. Furthermore they addressed the teachers' expectations of the impact on pupil learning and also how do these perceptions and expectations changed as a result of participating in this course of study. The key question that is addressed in this paper is :

What was the impact on pupil learning arising from the teachers' participation in this course of study?

Figure 2. Didactical design research framework

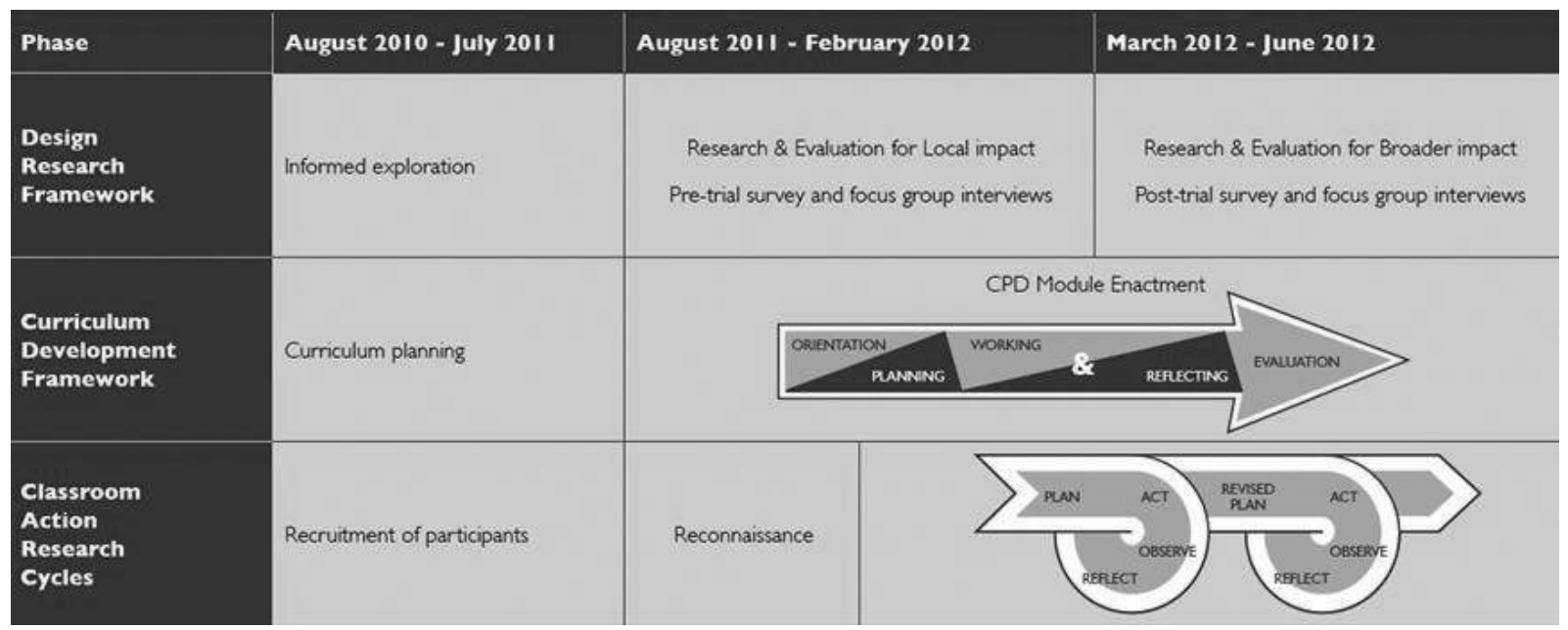

In this case the focus of development has been primarily on teachers' professional learning. The first phase of the design research framework took place in the first year of the project involving informed exploration and the design of the instruments and tools for gather data. This was carried out alongside the process of curriculum development as captured in the second row and also alongside the recruitment of the participants. Further phases took place in parallel implementation or enactment of the module and subsequently in parallel with the action research projects carried out by the participants.

\section{Research methods}

Empirical data in the main study were drawn from pre- and post-trial surveys of the teachers' perceptions, interviews with participants, observations of engagement in the online environment, document analysis of audits of classroom practice and action plans for classroom inquiry. The interviews focussed on teachers' perceptions concerning their levels of confidence and competence in relation to teaching mathematics; their attitudes and beliefs in relation to mathematics as a subject and their expectations of the impact on pupil learning arising from this course of study. Findings from main study are reported on in Hudson at al. (2014) and highlight the way the course had a transformational and emancipatory impact on these teachers. Also they highlight ways in 
which the 'framing' of particular aspects of the curriculum had an oppressive impact on learners in the ways that suppressed creativity and limited the exercise of learner autonomy. Furthermore they highlight the ways in which a number of these teachers had experienced mathematics as a school subject in very negative ways, involving high levels of 'symbolic violence' and of being 'labelled' as not being able to "do maths".

\section{THEORETICAL FRAMEWORK : JOINT ACTION THEORY IN DIDACTICS}

The theoretical framework adopted in this study is that of Joint Action Theory in Didactics (JATD), which is founded on what Sensevy (2011) describes as the first theoretical principle of French Didactics. This means that in order to understand a didactic activity (i.e. an activity where someone teaches and someone learns), one needs to understand a system, i.e. the didactic system, which is a system of three indivisible subsystems, "the subsystem of Knowledge (the piece of knowledge at stake), the subsystem of the Teacher, and the subsystem of the Student" (Sensevy, 2011, p. 60). This theoretical principal is consistent the notion of "tools for holding complexity" as discussed by Hudson (2002, p. 47/48). The didactic triangle is seen as a key tool for the analysis of the complex relations between teacher, student and content in the teaching/studying/ learning process, which ideally should be treated as a whole. In turn JATD is based on an understanding of joint action as a process of reciprocal semiosis (ibid. p. 61) involving the deciphering of verbal and bodily actions (or signs) of others in a particular situation.

In her discussion of the development of the Joint Action Theory in the context of the French disciplinary 'Didactiques', Lizogat (2011) traces the debates within the French-speaking research community and highlights how the very subtle differences related to language in use, e.g. les Didactiques, la didactique, le didactique and didactique, provide a 'symbolic system of the forces playing therein'. Her paper draws upon the anthropological approach of Yves Chevallard and explains how disciplinary didactiques came to be seen as too narrow for explaining and theorising 'didactical facts'. A particularly significant contribution lies in her description of the emergence of the field of 'la didactique comparée' or compara- tive didactics as the 'new kid on the block' in the landscape of the French-speaking didactical research community.

She describes the way in which concepts used within the sub-field of the didactics of mathematics came to be considered for their wider applicability across a range of subject-specific domains e.g. the concept of 'didactical transposition' arising from the work of Yves Chevallard and that of 'didactic contract' developed by Guy Brousseau. Questions raised related to the ways in which these concepts could be considered as describing some generic dimensions of the teaching and learning practices beyond 'epistemic specificity'. More generally, the question was raised as to how the epistemic specificity of the teaching practices could be empirically studied and distinguished from more generic forms of teaching that would be common to all topics. Associated questions related to methodological devices, empirical data, paradigms and the applicability of more general theories and concepts from the human and social sciences for building models in subject-specific didactics.

Her discussion shows how such questions progressively led to the outline of a new research field which was seen to be at the crossroads of disciplinary didactiques and in response to trends in human and social sciences such as social interactionism, linguistics and pragmatics. Taking the starting point of Chevallard's definition of la didactique as a horizon but not yet a reality, comparative didactics investigates the nature of didactical practices as a set of human actions that are purposively organised towards the diffusion of a socially legitimated culture and of individual transformation in knowing. The specific instances of didactical practices observed in classrooms and related to the subject matter organisation are the basis for comparison in order to illuminate some generic patterns of teaching and learning. The special issue of the 'Revue Française of Pédagogie' (Mercier, Schubauer-Leoni and Sensevy, 2002) is seen as marking the 'birth of comparative didactics in the French-speaking educational research community'.

Without claiming that the disciplinary didactiques can be subsumed directly into a single science of 'la didactique', comparative didactics has been established with the aim of starting a dialogue between existing disciplinary didactics in order to counteract the ever-growing fragmentation of asso- 
ciated research into many sub-themes ; providing methodological tools for enabling the comparison of didactical practices at different levels e.g. the classroom, teaching designs, conception of teaching resources and initiating reflection about how the learner makes sense of the contents encountered within each discipline. Lizogat also notes the way in which didacticians of mathematics pushed theoretical concerns the farthest, with two major theoretical elaborations which were firstly the 'Theory of Didactical Situations for Mathematics' by Brousseau (1997) and secondly the 'Anthropological Theory of Didactics' by Chevallard (1992) as an evolution of the 'Theory of the Didactic Transposition' (Chevallard, 1985/1991).

Joint Action Theory in Didactics (JATD) is seen to be a central concept of comparative didactics. Within such a theoretical framework, teaching and learning is envisioned as a joint action in which participants develop interdependent purposes and expectations. This is conceptualised as a 'didactic game' by Sensevy (2011), which is seen as 'the core of the logical structure of the teaching-learning process' (ibid p. 68). Key features of the joint action involved in this process are 'common ground, joint affordances, joint inferences and joint attention' (ibid. p. 68) which are used to help understand the joint didactic action of both teachers and students in the classroom setting. The teacher only achieves his or her goal, e.g. in ensuring that students learn a particular knowledge content, if the students get involved and act in a certain way. A fundamental constraint of this didactic game is the need for the teacher to be reticent (ibid. p. 69) in order to enable the student to learn on his or her own. The expected way of acting defines the logics of the learning progression in the 'didactic contract'. The specification of the joint action to the content being taught and learnt operates through the analysis of the nature of the epistemic activities that are to be achieved. This analysis is achieved by addressing the following questions :

What are the purposes of the activities presented in the teaching ?

What content could be leant from a general perspective?

To what bodies of practices may this task relate in the out-of-school culture (academic disciplines, professional practice)?

In overall terms JATD is seen to have borrowed some of its concept from major theories developed in didactique of mathematics, but has re-worked them in order to 'make room for the teacher and the student's agency within the institutional structures'. Further, given the basis of this theoretical framework involves an understanding of joint action as a process of reciprocal semiosis (Sensevy, 2011, p. 61), this perspective is consistent with the semiotic analysis underlying the discussion of mathematics as communication (Hudson et al., 2005).

\section{Key concepts used in this study}

The key concepts that are drawn from this theoretical framework and used in this study are that of a 'game', 'contract' and 'milieu'. In the relation to the first of these, the fundamental starting point for Joint Action Theory in Didactics, as described by Loquet (2011), is to consider teaching and learning as joint action, co-operative and asymmetric, between the teacher and the students, based on "language games" (Wittgenstein, 1997) specific to didactic systems. In particular three games are identified which might be seen in relation to the three aspects of the didactic triad i.e. teacher, content and learner. These are an 'Epistemic Game', a 'Didactic Game' and a 'Learning Game' respectively. An Epistemic Game refers to the game of the professional mathematician and two aspects this game are distinguished as follows. On the one hand the source epistemic game refers to the human practices that exist outside the didactic situation whilst on the other hand, the actual epistemic game is based on the analysis of class practices as they occur in situ. Secondly the Didactic Game relates to the game of the teacher in the didactic transactions between the teacher and the students. These are seen as games of a particular kind i.e. as games in which some specific pieces of knowledge are involved and as collaborative or joint games within joint action (Gruson, Loquet and Pilet, 2012, p. 65). Thirdly the Learning Game is the reciprocal game of the student in relation to the joint game.

The second key concept is that of the 'Didactic Contract' (Brousseau, 1997) which is used to describe the system of habits, which is largely implicit, between the teacher and the students in relation to the knowledge in question. On the basis of those habits established in the didactic institution, each participant (the teacher or the student) attributes some expectations to the other(s). The 
didactic contract provides a common background between the teacher and the students, against which the didactic transactions occur.

Finally the third key concept is that of the 'Milieu', which refers to the system of material and symbolic objects in question that corresponds to the new knowledge the students are to acquire. According to this description, the older pieces of knowledge enable the teacher and the students to act jointly whereas the new knowledge involves a kind of resistance to the student's action (Gruson et al., 2012, p. 65).

\section{RESULTS}

This main research question of this study addressed the impact on pupil learning arising from the teachers' participation in this course of study. In particular this focuses on the impact arising from the process of classroom inquiry through their action research projects. In order to address this question, the action research project of one teacher (Anna) is taken as an exemplar. This project was based on developing a topic-based approach to the teaching and learning of mathematics.

\section{Anna's action research project}

The project was framed within an overall approach to mathematical thinking based on one of the core texts of the course by Mason, Burton and Stacey (2010). Three broad phases are identified in responding to a mathematical question which are described as "entry, attack and review" as illustrated in Figure 3. These phases correspond to differing emotional responses to the question and also reflect whether or not progress is being made. Becoming aware of these phases is seen to enable the learner to deal more effectively with the situation.
Figure 3. Entry, Attack and Review phases in responding to a mathematical question

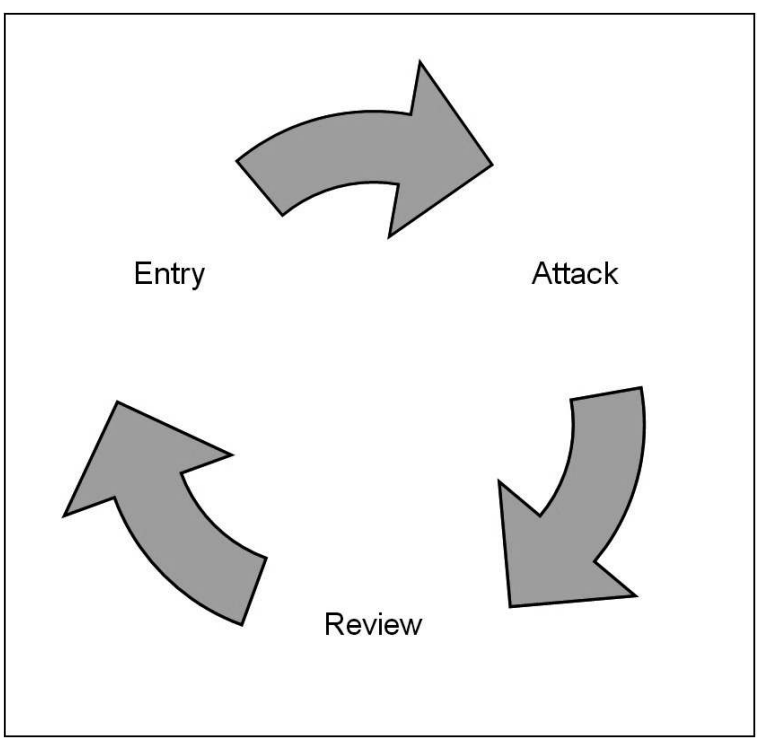

Anna's action research project was based on the following main question :

To what extent does topic-based mathematics allow children to demonstrate their mathematical thinking ?

Her related sub-questions were :

To what extent do topic-based mathematical questions allow children to verbalise their thinking ? What effect does topic-based mathematics have on children's levels of engagement ?

This study took place in a 5 class, rural primary school in Angus in North East Scotland, with a mixed age class of Year 5 and Year 6 pupils, aged between 9 and 11. The chosen topic for Anna's action research project was "The Rainforest" and as a result, twentythree pupils were given four questions to explore, analyse and record during a period of three weeks. The mathematical content was 'measurement' which primarily related to measurement of length and weight. The four questions that the pupils worked on were :

How could we measure these life-sized insects accurately?

How could we mark out the different layers of the rainforest in our playground?

Can you compare the length of the River Tay and the Amazon River?

Is there a relationship between the weight of an animal and the layer it lives on in the rainforest? 
Accounts of happenings in teaching and learning situations were recorded by collecting data in three ways. Firstly children's talk was recorded informally during conversations with peers, secondly notes were made of what children said during class feedback sessions and comments on the lessons in feedback sessions were recorded. Furthermore, observations were made of the levels of engagement within the class and various parts of the activities were filmed to watch and analyse at a later date.

Parental permission to seek children's consent was sought and 16 out of 23 parental slips were returned. All 16 gave permission for seeking children's consent for their quotes to be used anonymously. All pupils took part in the activities, however only those with parental permission who all gave their consent to be quoted were used in the data collection.

\section{Data analysis and interpretation using JATD}

Each of the four questions formed the focal point for one of four lessons during the three weeks period with each lesson running over several days. In this paper extracts from Lesson 1 and Lesson 3 only are used for analysis due to the extensive nature of the data relating to all four. Anna's account is then analysed by the researcher using the theoretical framework offered by Joint Action Theory in Didactics.

Lesson 1 : Measuring insects

Lesson 1 involved the question "How could we measure these life-sized insects accurately?". In her report Anna describes that the "learning intention" for this didactic game was for children to become confident in measuring with millimetres and to be able to convert between centimetres and millimetres. So in terms of JATD, the epistemic game was to be able to measure confidently with millimetres and to be able to convert between centimetres and millimetres.

The pupils were shown two life-size pictures of an Atlas moth and a Brazilian Huntsman spider and could choose which insect they wanted to investigate. From the start of the lesson, children actively discussed in pairs which insect they would choose and why. During feedback, many responses indicating enthusiasm and interest in the learning game were given.
Gillian (Year 6 girl) : "I'm wanting to measure the spider to see if its legs are all the same size." John (Year 5 boy, who is often disengaged.) : "I hate spiders. No way I'm measuring that ! I'll do the butterfly Jane (Year 5 girl.) : "Can I do the butterfly? Which bits should I measure though ?"

This comment and question led to the next part of the whole class discussion in which Anna posed the following question as part of the didactic game i.e. what parts should we be measuring ?

Once again the children engaged actively in the learning game and discussed this eagerly in pairs. It was noted at this point that all pupils were actively engaged. Anna saw this part of the lesson having clear correspondence to the "Entry Phase" described by Mason et al. (2010) since the children were slowly determining what they knew already and were building up strategies to solve the task. The children came to the conclusion that they could measure the "bits" of the insects that they thought were important. In terms of JATD, this phase could be seen as one in which the children were beginning to actively engage in the milieu i.e. the system of material and symbolic objects in question that corresponds to the new knowledge the students are to acquire.

The didactic game and associated classroom interaction continued with Anna posing the next question :

\section{Teacher : "What will you use to measure?"}

At this point a unanimous decision was made to use a ruler and one boy (Tony) was selected to demonstrate measuring one leg of the spider with a ruler. Tony selected a ruler, measured the leg from tip to tip and replied as follows,

Tony (Year 5 boy) : "It's about 8 centimetres."

The didactic game continued with Anna posing the next question and setting the next task:

Teacher: "Does that tell us exactly how long this leg is ? Discuss with your partner."

The children engaged in the learning game and four out of the twelve pairs realised that it wasn't an accurate reading because the leg was bent in different places. One Primary 5 child then came up with the 
idea of moving the ruler in different directions and another came up with the idea of moving the paper. These responses were praised by the teacher but after giving the children more thinking time, a Primary 6 girl (Josie), who usually had little self-confidence in her mathematical abilities, suggested using string to follow the leg and then to measure that. The teacher celebrated this idea and the other children agreed on this method. During learning game, pupils were actively listening to each other and keen to see the use of string to measure.

Anna continued by asking a further question and setting a further task as part of the didactic game :

Teacher: "As a rainforest researcher, would "about 8 centimetres" be enough information? Discuss this in your pairs."

Whisperings of millimetres could be heard in some pairs, particularly those with Primary 6 pupils present. The Primary 5 pupils had no formal experience of millimetres so this was a completely new concept for them. After the feedback session, it was agreed that measurements must be taken in millimetres to be more accurate. Each pupil was then given a ruler and millimetres were discussed. As part of the actual epistemic game, the root of the word "milli" was discussed and pupils were able to suggest related words such as millennium and millilitre. Children were then asked to measure fingers and fingernails etc. in millimetres and conversions were made between centimetres and millimetres. The teacher noted how all children were actively engaged throughout this practical measuring exercise, turning the rulers around to compare centimetres and millimetres which can be seen in terms of their active engagement in the milieu.

The pupils were then shown different ways of recording their findings by the teacher such as $1,1 \mathrm{~cm}, 1 \mathrm{~cm}, 1 \mathrm{~mm}$ and $11 \mathrm{~mm}$ as part of the on-going didactic game. Children were then given a piece of string each and then set the task to measure different parts of their chosen insect and to record their findings in their own way. During the measuring process, the teacher also asked the children to verbalise their thinking and demonstrate their measuring by way of advancing the learning game. Most children chose to write their measurements entirely in millimetres only.
In this first example, a Year 6 girl (Kaye) wrote short sentences to describe her measurements and when asked by the teacher why she used millimetres, she said, "It's easier to see the numbers this way. It's weird, they're all (the spider's legs) different lengths mostly."

Figure 4. Kaye's measurements of the spider

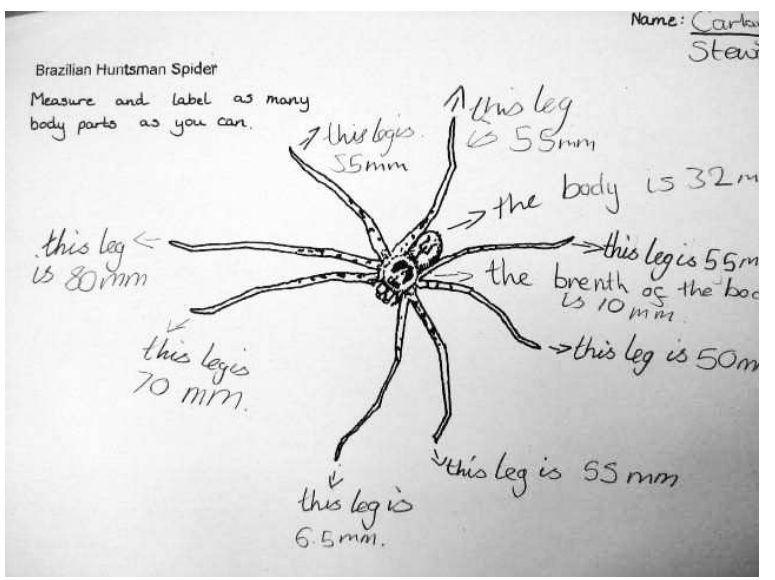

This demonstrates how Kaye was actively involved in the learning game and how she was concerned not only with measuring but also with the clear presentation of her results as part of the actual epistemic game.

In the second example, a Year 5 girl (Jenny) chose to estimate her answers first without being prompted. When asked about it, she replied, "I wanted to try to use my eyes first to see how big the butterfly's wings were. I thought the top ones were bigger and I was right but my guesses were too small."

Figure 5. Jenny's measurements of the moth

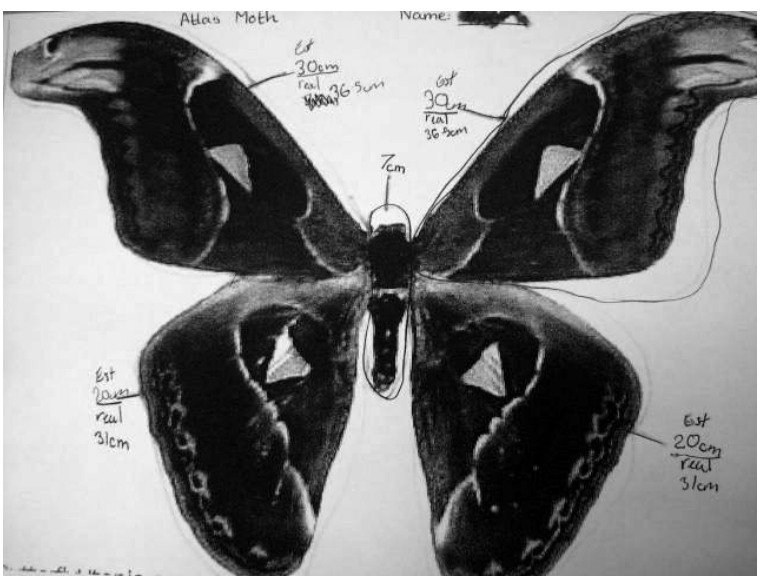


This demonstrates how Jenny was actively involved in the learning game and how she was concerned both with estimation as well as measuring as part of the actual epistemic game.

The third example was by a Year 5 boy (Paul), who was described by the teacher as a high achieving pupil, and who eagerly wanted to show the teacher his work. "Mrs A, I've done all three ways. They are totally the same on each side, look. Have I missed any bits?"

Figure 6. Paul's measurements of the moth

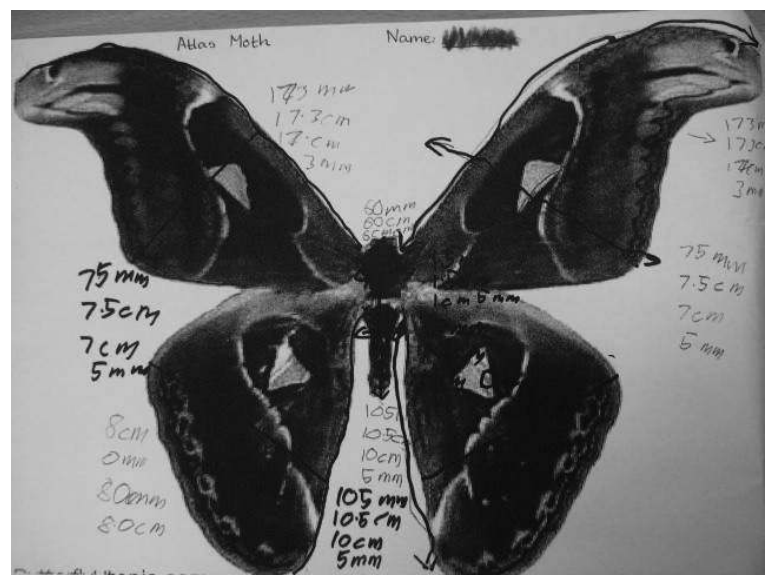

This demonstrates how Paul was actively involved in the learning game and how he was able to use both centimetres and millimetres as part of the actual epistemic game.

The final example is by a Year 5 boy (John) who was described by the teacher as a low achiever in mathematics. He was slowly measuring the body of the butterfly and on observation he was being meticulous. He recorded his findings in centimetres and in millimetres and said that, "The body is exactly six centimetres; I don't need millimetres for that one."
Figure 7. John's measurements of the moth

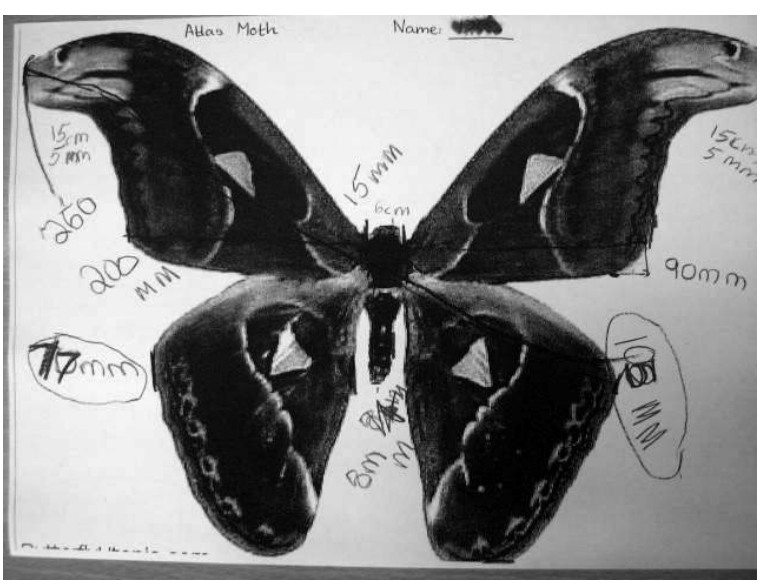

This demonstrates how John was actively involved in the learning game and how he was able to see the relation between centimetres and millimetres, dispensing with the need to use the latter on this occasion, as part of the actual epistemic game.

Overall, the children were able to respond to the questions and used the parts of the insects in their verbal responses during the plenary. Many pupils were also able to participate in the learning game by commenting on the symmetrical qualities of the animals, which led into an extension of the didactic game through a discussion on symmetry. This aspect is discussed further in relation to the actual epistemic game in the final discussion. The lesson as a whole could be seen as one in which the children actively engaged in the milieu. It also demonstrates the way in which the didactic contract provides a common background between the teacher and the students, against which the didactic transactions occurred. Furthermore it illustrates the dialectic between the contract and milieu through effective teacher questioning through the didactic game and resulting responses from the students in the learning game.

Lesson 3 : Comparing the lengths of the River Tay and the Amazon

The didactic game was continued in Lesson 3 by addressing the question of "Can you compare the length of the River Tay and the Amazon River ?" Anna described her expectation as the teacher for the children to be able to "discuss length confidently in kilometres and to demonstrate an understanding of the enormity of the Amazon River in relation to the River Tay." This provided the basis for the source epistemic game for this lesson. Prior to the lesson, the children had investigated the length of a kilo- 
metre and most were able to convert between metres and kilometres.

To begin the activity, children had 30 minutes to research the lengths of the two rivers by making use of the Internet.

A Year 5 boy (Andrew) explained his thinking as part of the learning game as follows :

Andrew (Year 5 boy) : "The Amazon is like a snake, so some people might be measuring it from when it's just a wee stream and some might just be measuring it from the start of the big river."

This example can be seen as one in which Andrew was beginning to actively engage in the milieu.

As part of the didactic game, the children were then asked by Anna to present their findings in a sentence, paragraph or diagram. Anna saw this as a successful exercise for observing and recording the children's understanding of kilometres in a relaxed but focused atmosphere. Some findings of the children are listed below which illustrate the learning game :

A Year 5 boy (Joseph) simply noted that :

Joseph (Year 5 boy): "The Tay is shorter than the Amazon."

Another Year 5 boy (Andrew) went further :

Andrew (Year 5 boy) "The Amazon is the second biggest river in the world at around an amazing 6400 kilometres long. So the Amazon is longer."

A Year 6 boy (Keith) described a more extensive use of the internet:

Keith (Year 6 boy) "We only found our results in miles but we found an online converter and put them both into kilometres."

A Year 5 girl (Karen) stated that :

Karen (Year 5 girl) "We took away 193 from 6360 to find the difference between the two rivers."

This comment intrigued the rest of the class and prompted the activity of repeating the calculation to see if Karen had calculated correctly as part of the actual epistemic game.

Anna describes how, following this activity, a Year 5 boy (John) wanted to explain the diagram he had created with his partner.
John (Year 5 boy) stated, "I drew the Amazon and the River Tay on my piece of paper. I measured the paper and it was about 300 millimetres so we narrowed it down and got that every 5 centimetres was about 1000 kilometres. The River Tay is only 186 kilometres so it's only that size"

She describes how he then pointed to the part of their diagram labelled "River Tay" at the very bottom of the page that is illustrated in Figure 8.

Figure 8. John's drawings of the River Tay and the River Amazon

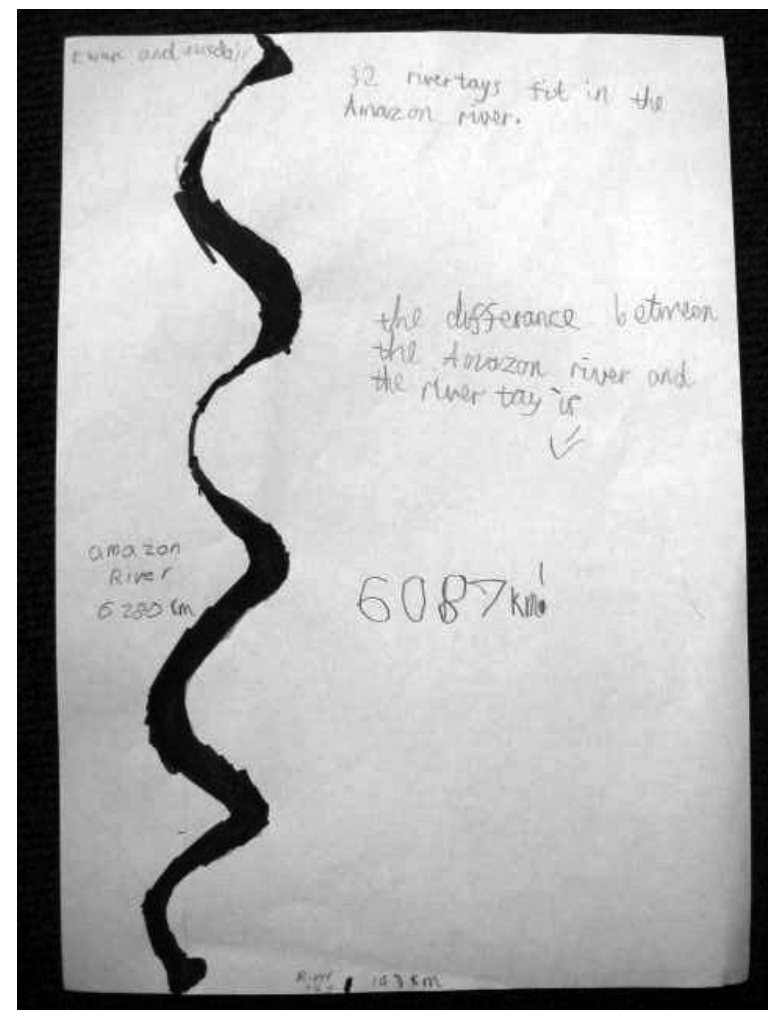

Anna noted how this comment and diagram not only confirmed John's 'understanding' of kilometres, but also how it demonstrated his 'understanding' of centimetres and millimetres too. Furthermore she noted how from the teacher's perspective it had been excellent opportunity to not only see the children's mathematical thinking unfold in their diagram, but also listen to their explanation and to observe their enthusiasm, thus illustrating her thinking behind the didactic game. The other children in the class were very interested in this and one Year 6 girl (Tracy) continued the learning game in commenting that : 
"The Tay is tiny compared to that, you could fit like, a hundred of the Tay into the Amazon!" (Tracy)

Anna notes how this comment was explored and extended, which can be seen as part of the learning game, leading to her question, which extended the didactic game further :

"How many times would the Tay fit into the Amazon River ?" (Anna)

In her subsequent presentation to the School Research conference some weeks after completing the course, Anna described this as a "light bulb moment" and this aspect is discussed further in the concluding discussion to this paper.

As part of the on-going learning game, one Year 6 boy (Michael) suggested that both the numbers should be rounded off to make it easier. In response, a Year 6 girl (Charlotte) said :

"That would be... 190 kilometres ?"

Michael then replied : "It'd be good to do it to 200, to the hundred instead."

As part of the didactic game, Anna organised the class to vote on the two suggestions and it was decided to work to the nearest hundred thus extending the epistemic game. Children were then set to task to solve this problem in pairs. Various methods were demonstrated, and two examples of children's working are shown below. To finish the lesson, the results were discussed and strategies explained.
Figure 9. First example of a child's working

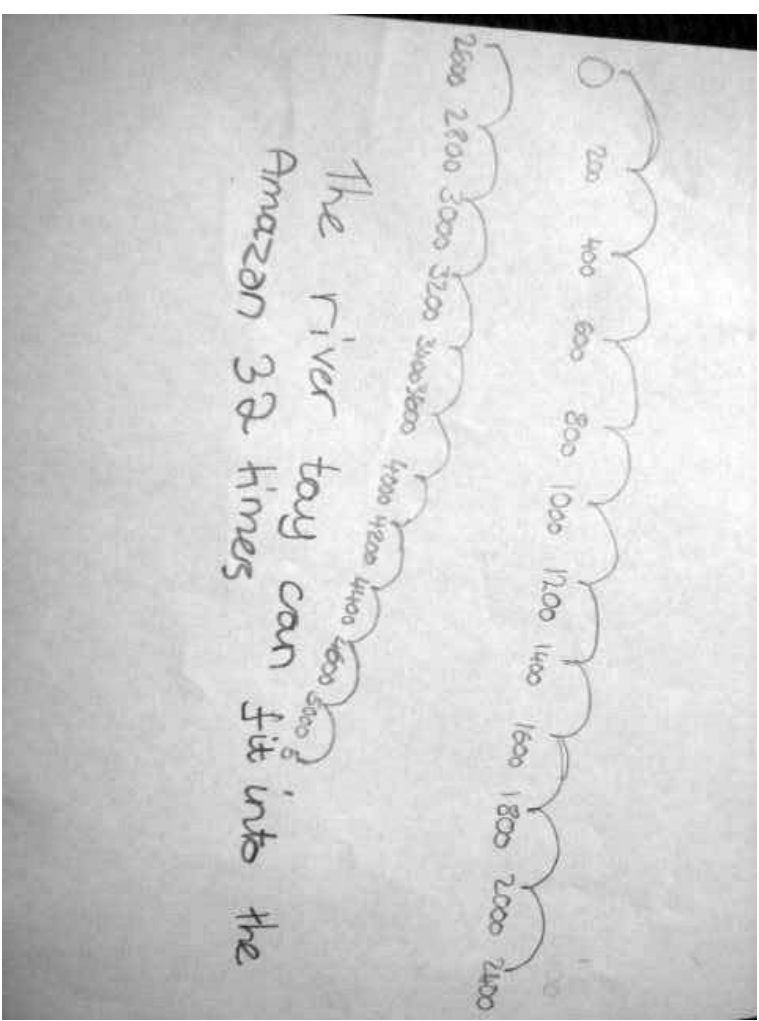

Figure 10. Second example of a child's working

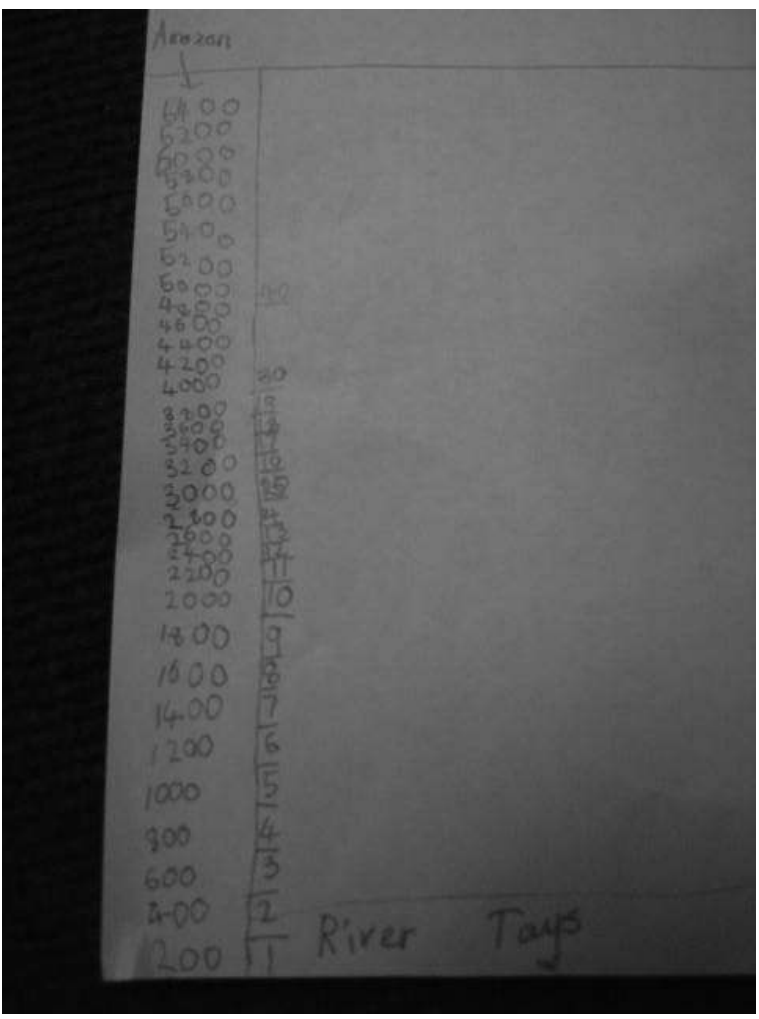


Here are two examples of the feedback as part of the learning game, which highlight the development of the children's mathematical thinking as part of the actual epistemic game.

"I did 200,400,600,800 and 1000, so there's 5 River Tays in 1000. That means there's 30 in 6000 because 5 times 6 is 30, Then I just needed two 200s to get the 400 kilometres left. So the Amazon is about 32 River Tays."

"I did 6400 divided by 200 as a sum to find out how many River Tays I could get in the Amazon. I said, "How many two hundreds are in 6, none, in 64 none, in 640, 3 with 40 left over. Then I put that 40 with the zero in the units column and got two hundreds in 400. That made 32."

In her analysis, Anna describes how the discursive element of this lesson proved to be a very effective tool to assess the pupils' understanding and mathematical thinking and this aspect is discussed further in the final section. In terms of JATD, the lesson as a whole could be seen as one in which the children actively engaged in the milieu, the way in which the didactic contract provides a common background and also the way in which dialectic operated between two through effective teacher questioning and resulting responses from the students.

\section{DISCUSSION}

In both of these lessons, we are able to share Anna's observations of the ways in which the children actively engaged in the milieu i.e. the system of material and symbolic objects in question that corresponds to the new knowledge the students are to acquire. Both lessons also demonstrate the way in which the didactic contract provides a common background between the teacher and the students, against which the didactic transactions occur and also the dialectic between the contract and milieu.

Anna's analysis represents the actual epistemic game based as it is on the analysis of class practices as they occur in situ. Her analysis of the didactic game in relation to each lesson provides a detailed description of the milieu. For example in Lesson 1 she provides a picture of the ways in which children engage actively in the milieu from the point at which they came to the conclusion that they could choose to measure the "bits" of the insects that they thought were important through to the point at which they were able to respond to the questions and to use the parts of the insects in their verbal responses during the plenary. Furthermore she highlights the way in which this engagement in the milieu corresponded to the "Entry Phase" (Mason et al., 2010) of mathematical problem solving by reflecting on previous knowledge and by building up strategies to solve the task. She also notes that many pupils were also able to comment, as part of the learning game, on the symmetrical qualities of the insects, which led into a short discussion on symmetry, thus highlighting the potential to extend the source epistemic game through the use of the open-ended topic-based approach combined with effective teacher questioning.

In her analysis of Lesson 3, Anna noted that, as with the previous lessons, it was evident that the children were able to take their investigation further according to their level of understanding and previous knowledge. A particularly significant aspect of Lesson 3 is the incident that Anna described as a "light bulb moment" in her subsequent conference presentation. This marked a moment in time when the source epistemic game became modified and extended due to the open-ended nature of the actual epistemic game combined with Anna's didactic ability to respond in the moment and to build on her pupils' remarks. Anna notes how the comment from Tracy about how tiny The River Tay is compared to the Amazon and that "... you could fit like, a hundred of the Tay into the Amazon!" was explored and extended leading to the question "How many times would the Tay fit into the Amazon River ?" Anna's question as part of the didactic game extended the actual epistemic game into one which was concerned with estimation, scale and calculations involving addition, subtraction, division and multiplication with up to four digit numbers. Of course the initial epistemic game contained the potential for this extension given that it was based on the children developing the ability to "demonstrate an understanding of the enormity of the Amazon River in relation to the River Tay". Anna's original "learning intention" for this didactic game was for children to become confident in measuring with millimetres and to be able to convert between centimetres and millimetres. However the children's mathematical thinking was extended to consideration of the concept of scale, which involved estimation and also calculations involving addition, subtraction, division and multiplication with up to four digit numbers. Since 
all pupils recognised the vast difference between the rivers, their natural inquisitiveness drove them to extend their own thinking and the thinking of others. The question in Lesson 3 in particular developed tremendously throughout the lesson. It was evident in this study that children had very differing prior knowledge and experiences to bring to the problem solving elements of the tasks and that, due to their ability to visualise the problems, the mathematics became more accessible leading to an evolution in mathematical thinking for all.

\section{RÉFÉRENCES}

Boaler, J. (2009) The Elephant in the Classroom. London : Souvenir Press Ltd.

Brousseau, G. (1997) Theory of Didactical Situation in Mathematics. Dordrecht : Kluwer Academic Press

Chevallard, Y. (1992). Fundamental Concepts in didactics : perspectives provided by an anthropological approach. Research in Didactique of Mathematics. Selected papers (pp. 131-167). Paris \& Grenoble : ADIREM \& La Pensée Sauvage

DMTPC (2012) Developing Mathematical Thinking in the Primary Classroom, retrieved February 13, 2014, from http://discovery.dundee.ac.uk/portl/files/2013136/_3e_ DMTPC_report.pdf/Gruson, B., Loquet, M. and Pilet, G. (2012) Analyzing Semiosis Process in Primary Classrooms : Case Studies in Second Language and Gymnastics, International Colloquium on Forms of Education and Emancipation Processes, Centre for Research in Education and Didactics (CREAD), Rennes, 22-24 May 2012

Hudson, B., Henderson, S. and Hudson, A., (2015) Developing Mathematical Thinking in the Primary Classroom : Liberating Teachers and Students as Learners of Mathematics, Journal of Curriculum Studies, 47(3), 374-398. http://www.tandfonline.com/doi/pdf/10. 1080/00220272.2014.979233

Hudson, B. (2011) Didactical Design for Technology Enhanced Learning. In B. Hudson and M. Meyer (Eds.) Beyond Fragmentation: Didactics, Learning and Teaching in Europe, 223-238. Opladen and Farmington Hills : Barbara Budrich Publishers

Hudson, B., Ongstad, S. and Pepin, B. (2005) Mathematics Education : Teaching-learning in Situational and Communicational Contexts. In S. Ongstad, B. Hudson, B. Pepin, G. Imsen and P. Kansanen (Eds.) Didaktik and/in Mathematics Education. Studying a Discipline in International, Comparative and Communicational Perspectives, 83-185. Oslo : Oslo University College

Hudson, B. (2002) Holding complexity and searching for meaning - teaching as reflective practice. Journal of Curriculum Studies, 34(1), 43-57
IEA (2008) Trends in Mathematics and Science Survey 2007 (Lynch School of Education, Boston College : International Association for the Evaluation of Educational Achievement)

Lizogat, F. (2011) The Development of the Joint Action Theory in the Context of the French Disciplinary 'Didactiques', Symposium on Fachdidaktik - European Perspectives, European Conference of Educational Research, Freie Universität Berlin, 13-16 September 2011

Mason, J., Burton, L. and Stacey, K. (2010) Thinking Mathematically, Harlow : Prentice Hall

Mercier, A., Schubauer-Leoni, M.-L. \& Sensevy, G. (2002) Vers une didactique comparée. Revue Française de Pédagogie, 141, 5-16

Nédelec-Trohel, I. and Forest, D. (2012) Studying the didactic semiosis of an aid device designed to help students with learning difficulties in mathematics, International Colloquium on Forms of Education and Emancipation Processes, Centre for Research in Education and Didactics (CREAD), Rennes, 22-24 May 2012

OECD (2007) Reviews of National Policies for Education - Quality and Equity of Schooling in Scotland, OECD Publishing. doi : 10.1787/9789264041004-en

Sensevy, G. (2011). Overcoming fragmentation : Towards a joint action theory in didactics. In Hudson, B. \& Meyer, M. A. (Eds.) Beyond Fragmentation: Didactics, Learning, and Teaching (pp. 60-76). Verlag Barbara Budrich, Opladen and Farmington Hills

Scottish Executive Education Department (2007), OECD Review of the Quality and Equity of Education Outcomes in Scotland: Diagnostic Report. Retrieved January 24, 2012, from www.oecd.org/edu/reviews/nationalpolicies

Scottish Executive Education Department (2005) Assessment of Achievement Programme : Seventh Survey of Mathematics 2004 (Edinburgh : Scottish Executive Education Department)

Scottish Government (2009) 2008 Scottish Survey of Achievement: Mathematics and Core Skills. Retrieved March 31, 2009, from http://www.gov.scot/resource/ doc//268855/0079915.pdf

Wittgenstein, L. (1997). Philosophical Investigations = Philosophische Untersuchungen (G.E.M. Anscombe, Transl.), Oxford : Blackwell. (Original work published 1953) 